ELORE (ISSN 1456-3010), vol. $12-2 / 2005$.

Julkaisija: Suomen Kansantietouden Tutkijain Seura ry. Taitto: Jukka Talve ja Outi Fingerroos. [http://cc.joensuu.fi/ /oristi/2_05/vil2_05.pdf]

\title{
NeITSYT Maria SYNNYTYSLOITSUISSA
}

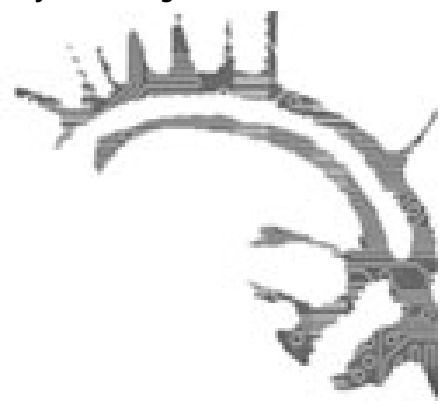

Maarit Viljakainen

Neitsyt Maria on suomalaisten ja karjalaisten loitsujen voimanainen. Suomen Kansan Vanhat Runot-sarjan loitsuissa Marian nimi mainitaan muita yliluonnollisia tai pyhiä henkilöhahmoja useammin. Rukouksissa ja loitsuissa on satoja Mariaan liittyviä aihelmia, jotka ovat niin esikristillistä Marialle siirtynyttä perimää kuin yleiskristillistä kulkutavaraa. Neitsyt Maria tunnetaan Länsi-Suomessa ja Karjalassa, missä Mariaan on vedottu sekä luterilaisilta että ortodokseilta muistiinpannuissa loitsuissa. Neitsyt Marian hahmo on voimallinen ja erikoislaatuinen juuri Karjalassa, missä idän ja lännen kirkot ja kulttuurit sekä vahva, poikkeuksellisen pitkään säilynyt kansanusko ovat kohdanneet toinen toisensa ja eläneet vuorovaikutuksessa keskenään. Maria erottuu kaikista Karjalan uskonnollisista piireistä, mutta hän on saanut osakseen niin kirkollisissa kuin kansanomaisissa traditioissa toisistaan poikkeavia tulkintoja (1). Senni Timonen kirjoittaa, että Marian hahmo konkretisoituu ja Maria-aihelmat muuttuvat runsaammiksi, mitä idemmäksi liikutaan. Läntisen Suomen Mariaan vetoavat loitsut ovat suppeita ja muistelevat kaukaa Marian menneisyydessä suorittamia toimia. Idempänä ja varsinkin ortodoksisessa Karjalassa Maria elävöityy ja häntä puhutellaan suoraan etenkin naisten elämänpiiriin kuuluneissa asioissa kuten synnytyksissä. (Timonen 1990,111-114.)

Tässä artikkelissa tarkastelen synnytysloitsuissa esiintyviä Maria-aihelmia. Maria on synnytysloitsujen suosituin yliluonnollinen avustajahahmo. Synnytysloitsuissa Marian apua kaivataan ja hänen taitoihinsa vedotaan ahkerasti niin Karjalassa kuin Pohjois-Pohjanmaalla ja Savossa. Minkälaista Neitsyt Mariaa synnytysloitsuissa puhutellaan? Miksi ja miten Mariaan vedotaan? Mitä häneltä pyydetään? Tarkastelen Marian olemusta, apuun kutsua ja häneltä pyydettyä apua. Artikkelini pääasiallinen aineisto muodostuu Raja-Karjalasta, Pohjois-Karjalasta, Etelä-Karjalasta, Vienasta, Savosta ja Pohjois-Pohjanmaalta kerätyistä ja Suomen Kansan Vanhat Runot-teossarjaan (SKVR) tallennetuista Neitsyt Mariaan vetoavista synnytysloitsuista (2). Aineistoni koostuu 94 loitsusta: Raja- ja Pohjois-Karjalassa Maria on läsnä 32 loitsussa, Etelä-Karjalassa 9 loitsussa, Vienassa 23 loitsussa, Savossa 18 loitsussa ja Pohjois-Pohjanmaalla 12 loitsussa. Kaiken kaikkiaan näiltä alueilta kerättyjä synnytysloitsuja on julkaistu SKVR:issa 205 kappaletta. Keskityn artikkelissani ensisijaisesti Maria-aihelmien ja synnytysloitsutekstien analyysiin. 


\section{MaARIT ViLJAKAinen}

Synnytysloitsut on aikaisemmassa tutkimuksessa huomioitu useimmiten niissä esiintyvien yliluonnollisten avustajien, etenkin Neitsyt Marian ja Ukko ylijumalan ansiosta (esim. Haavio 1967, 167-168; Krohn 1915, 219-220; Porthan 1982, 26). Synnytysloitsuihin on viitattu myös luonnollisesti kansanomaista synnytyskulttuuria ja synnytysapua sekä naisten magiaa käsittelevissä tutkimuksissa (Helsti 2000; Keinänen 2003; Paulaharju 1924; Pelkonen 1931; Stark-Arola 1998). Lisäksi Lotte Tarkka on käsitellyt vienankarjalaisten synnytysloitsujen symboliikkaa artikkelissaan Tuonpuoleiset, tämälmanen ja sukupuoli; raja vienankarjalaisessa kansanrunoudessa (1990). Tarkan artikkelin keskeinen ajatus synnytysloitsujen kohdalla on lapsen tekemä"matka" tai siirtymä tuonpuoleisesta tilasta "tämänilmasiin" eli ihmisten maailmaan.

Suomen Kansan Vanhat Runot-sarjaan on tallennettu yli 30000 erilaista loitsua eli kalevalamittaista tai suorasanaista riittirunoa, jotka elivät ihmisten arjessa ja erilaisissa muissa sosiaalisissa tilanteissa aina 1900-luvun alkupuolelle asti. Loitsujen osaaminen oli hyödyllinen ja käytännöllinen taito, sillä niiden avulla torjuttiin ja parannettiin erilaisia vammoja ja sairauksia sekä turvattiin onni maanviljelyksessä, metsästyksessä, kalastuksessa ja karjanhoidossa. Lisäksi esimerkiksi lemmenloitsuilla oli mahdollista parantaa omaa vetovoimaisuuttaan avioliittomarkkinoilla ja häissä luetuilla loitsuilla saattoi suojella uuden pariskunnan avio-onnea. (Piela 1989, 8283.)

SKVR:ihin on muistiinpantu kaiken kaikkiaan noin 300 synnytysloitsua, jotka on pääasiassa sijoitettu tautiloitsujen joukkoon (3). Synnytysloitsujen tehtävänä on ollut ennen kaikkea synnytyskipujen lievittäminen ja synnytyksen edistäminen. Loitsuille annetut otsikot kertovat kenelle ja mihin tarpeeseen loitsut on tarkoitettu: "Lapsi vaimon loihtu" (SKVR VII 4 3010), "Lasten suamisen vaivoissa" (SKVR VII 4 3008) ja "Lapsen synnyttämiseen" (SKVR VI 2 4638). Loitsut on myös tarkoitettu tilanteisiin, joissa "lapsi ei tahtonut syntyä" (SKVR XII 26223 ), "vaimo ei taho päästä erilleen hyvästi" (SKVR XII 2 6238) ja "jos vaimon on vaikea synnyttäă” (VI 4653$)$. Joidenkin loitsujen ohessa on kuvailtu paikoitellen erittäin tarkasti erilaisia maagisia menetelmiä, joiden suorittaminen loitsimisen yhteydessä on ollut tilanteen selvittämisen ja parhaan lopputuloksen kannalta ilmeisen suotavaa (esim. SKVR VII 4 3033, 3034, 3046, 3065; SKVR I 941, 942, 943, 951).

Suomalainen 1800-luvun synnytyskulttuuri on ollut varsin moninainen ilmiö. Lapsensaantia ohjasi kansanuskon ja -lääkinnän traditio, joka oli sekä vahva ja pitkäkestoinen että sovelluksille ja uudelleentulkinnoille altis. Jokaisella äidillä, perheellä ja synnytysavustajalla oli omat tapansa toimia ja hyödyntää tuntemaansa perinnettä aina tarpeen niin vaatiessa. Uskonto, perheen elintaso, äidin aikaisemmat synnytykset ja terveydentila, saatavissa oleva apu ja jopa vuodenaika vaikuttivat omalta osaltaan siihen, kuinka synnytys tapahtui. (Helsti 2000, 61.) Hilkka Helstin (2000) ja Marja-Liisa Keinäsen (2003) kansanomaista synnytyskulttuuria ja synnytysapua Suomessa ja Karjalassa käsittelevistä tutkimuksista käy ilmi, että naiset synnyttivät lapsensa työn lomassa pelloilla ja metsissä tai pihapiirin eläinsuojissa ja saunassa. Yksinsynnyttämistä suosittiin etenkin Karjalassa, mikäli synnytys sujui ilman erityisiä ongelmia. (Helsti 2000, 74, 125-137; Keinänen 2003, 120, 127-128; myös Pentikäinen 1971, 156.) 


\section{NEITSYT MARIA SYNNYTYSLOITSUISSA}

Synnytyskipuja lievittävistä keinoista tärkeimpiä olivat loitsut (Helsti 2000, 77). Loitsuja ja muita maagisia menetelmiä tarvittiin etenkin silloin, kun synnytys jostakin syystä vaikeutui. Usein synnytysongelmien nähtiin olevan peräisin kanssaihmisistä. Synnyttäjä oli altis esimerkiksi "rikkeille" ja pahalla silmällä aiheutetulle harmille. Raskauden ja synnytyksen salaaminen näyttää olleen suhteellisen yleinen käyttäytymisnormi muuten vaihtelevien käsitysten ja käytänteiden joukossa. Kun synnyttäjä ei enää selvinnyt yksin syystä tai toisesta, auttoi häntä kulloisestakin tilanteesta riippuen anoppi, maallikkokätilö, poapo tai vaikeimmissa tapauksissa tietäjä, joka muun muassa omilla loitsutaidoillaan pyrki pelastamaan synnyttäjän ja lapsen. Loitsut, moninaiset maagiset menetelmät ja käytännön toimet kuten hierominen, kävelyttäminen, oksennuttaminen, viinan tai varta vasten valmistettujen nesteiden juottaminen ja äidin voiteleminen muodostivat rituaalisen kokonaisuuden äidin ja lapsen auttamiseksi (4). (Paulaharju 1924, 23-31; Pentikäinen 1971, 156-158; Helsti 2000, 71-72, 75-79; Keinänen 2003, 120-133.)

\section{YLILUONNOLLINEN APU}

Synnytysloitsuissa silmiinpistävää on se, että lähes jokaisessa loitsutekstissä vedotaan johonkin yliluonnolliseen tai pyhään olentoon. Ilomantsista muistiinpannussa loitsussa kysytään, että

$$
[. .]
$$

Mistäpäs anon apua,

kustas etsin huojennosta?

Tuoltapa anon apua,

tuolta buuan huo istusta:

isältäni Jesukselta,

äitiltäni Maarialta;

tuolta aina armot käypi,

turvat tuttavat tulevat

isältäni Jesukselta,

äitiltäni Maarialta.

[..]

(SKVR VII 4 3056, anonyymi, Ilomantsi, Europaeus 1845.)

Iisalmelta tallennetussa loitsussa todetaan myös suoraan ja osuvasti, että "Ei ole apua ihmisistä, / eikä turvaa tuttavista" (SKVR VI 2 4662). Rautjärveltä muistiinpannussa loitsussa pohditaan puolestaan samaa asiaa seuraavanlaisesti:

[..]

Ei ole suvussa tässä,

tässä laajassa lajissa

tämän pulman purkajata, 
tämän jakson jaksajata.

Turvaumme tuonnemmaksi

entisibin eläjibin,

joilta aina armot käjvät,

turvat totiset tulevat.

[..]

(SKVR XIII 3 9492, Anni Jyrkinen, Rautjärvi, Häyhä.)

Loitsijat ovat siis tunteneet ilmeistä tarvetta kutsua itsensä, synnyttäjän ja lapsen avuksi ihmistä vahvempia voimia (5). Kysymys on ollut elämästä ja kuolemasta, minkä vuoksi on ymmärrettävää, että tilanteen selvittäminen on mieluusti luovutettu korkeampien ja vahvempien voimien haltuun. Ainakin synnyttäjän maallinen avustaja on voinut jakaa osan vastuusta yliluonnollisten avustajiensa kanssa. Kaiken kaikkiaan synnytysloitsuissa esiintyy kirjava joukko niin kristillisiä kuin kansanuskon piiriin kuuluvia avustajaolentoja. Synnytysloitsuissa tunnetaan Neitsyt Maria, Ukko ylijumala, Jumala, Jeesus, Luoja, Kave eukko, Saunatar, Kipu tyttö, Synnyttäret, hiisi, ukko ja ämmä Turjan maalta, Loviatar, merestä nouseva musta mies, vainajat sekä prototyyppiset tietäjät Väinämöinen ja Lapin noita. Lisäksi eläinhahmoiset avustajat - koira, hevonen, kotka ja erilaiset kalat - auttavat omalla tavallaan. Aineistossani Neitsyt Mariaa on anottu apuun ahkerimmin, mutta hän ei siis kuitenkaan ole ainoa yliluonnollinen avustajahahmo (6). Avustajat lievittävät pääasiassa synnyttäjän tuskia, avaavat synnytystiet lapsen tieltä ja vahvistavat loitsijaa tämän toimissa. Aineistoni loitsuissa vedotaan usein avustajan aikaisempiin ihmeellisiin tekoihin: "sinä kuun kehästä päästit, / päivän pilvestä selitit, / tule, päästä tääkin päästö” (SKVR VII 3 3031). Minkä takia tämä ei auttaisi pientä ihmistä maailmaan, kun hän on maailman peruselementitkin onnistunut luomaan?

Synnytysvaikeuksia ratkoneet loitsut rakentuvat pitkälti yliluonnollisen maailman kanssa kommunikoimisen varaan. Avustajan nimeäminen, apuun kutsuminen, avunpyynnön syyn selittäminen ja toivomukset tarvittavan avun suhteen ovat synnytysloitsuille ominaisia aihelmia. Sekä yliluonnollisen avustajan puhuttelu että tämän olemuksen ja toiminnan kuvaus ovat keskeinen osa loitsua, minkä vuoksi synnytysloitsut edustavat kommunikatiivista loitsutyyppiä. Loitsujen sävy on maanitteleva, lempeä ja keskusteleva. Tämänkaltaiselle loitsutyypille on ominaista yhteisöhakuisuus ja vahva "me"-henki, mikä välittyy myös synnytysloitsuista. Yliluonnollinen avustaja, loitsija, synnyttäjä ja lapsi ovat jokainen vahvasti läsnä loitsussa. Yliluonnollisten avustajahahmojen puhuttelu on tyypillistä itäsuomalaisille ja karjalaisille loitsuille. Loitsijat tavoittelevat suoraa yhteyttä niin avustajaolentoihin kuin myös karkotettaviin taudinaiheuttajiin ja pahantekijöihin mekaanisen loitsinnan sijaan. Manaukset ovat luonteeltaan yhtä lailla kommunikatiivisia. Tällöin loitsijan äänensävy tosin muuttuu radikaalisti: hän pakottaa, käskee ja uhkaa vastustajaansa. (Piela 1989, 104-105.)

Neitsyt Mariaan ja muihin yliluonnollisiin avustajiin vetoaminen ei ole ollut kuitenkaan vain synnytysloitsujen yksinoikeus. Kaarle Krohn kirjoittaa (1915, 218), että "loitsuissamme käännytään Neitsyt Marian puoleen mitä erilaisimmissa 
tarpeissa; sillä hänen kauttaan on uskottu saatavan, mitä ikinä anottiin”. Maria onkin toiminut loitsuissa yleisavustajana, johon on voitu turvautua muun muassa kalastuksessa, metsästyksessä, karjanhoidossa, lemmennostossa, ulkoisten vammojen hoidossa ja myös synnytyksissä. Marian rooli on ollut lempeän hoivaava ja kipuja lieventävä: hän on ollut aivan ihanteellinen sairaanhoitaja. (Krohn 1915, 218-222; Siikala 1996,173-174.) Senni Timosen mukaan $(1990,114)$ etenkin ortodoksisessa Karjalassa Marialle kohdistetaan suoria vetoomuksia, rukouksia ja pyyntöjä, jotka keskittyvät naisten elämänpiiriin eli synnytyksiin, tyttöjen lemmennostoon sekä ihmisten ja karjan parantamiseen.

Synnytysloitsuissa selvitetään myös muiden parannusloitsujen lailla taudin alkuperää ja karkotetaan taudinaiheuttajia. Taudin alkuperän tiedusteluissa kysytään, että kuka tai mikä on saattanut synnyttäjän tukalaan tilaan (esim. SKVR $\mathrm{XII}_{2}$ 6211, 6214; SKVR I 960, 963, 974, 979). Synnytysloitsuissa alkuperän tiedustelut ovat useasti kysymyksiä, joissa nostetaan esille mahdollinen syypää: "onko kiukuissa kiroissa, / miesten mielimurteloissa, / muorien salasanoissa" (SKVR I 963). Usein epäiltyinä ovat toiset ihmiset ja heistä peräisin olevat kirot, kateet tai silmäykset. Kateen sanoja on käytetty muutamassa aineistoni loitsussa (SKVR I 961; SKVR VII 3015,3018 ). Yhtä lailla muutamassa aineistoni loitsussa tuodaan ilmi, että ongelmien aiheuttajan synty on selvästi tiedossa ja vähäteltävissä (SKVR VII $_{4}$ 3044, 3048; SKVR VI 2 4654). Myös kipujen syntysanoja on käytetty synnytysloitsujen osina (SKVR VI 2 4646; SKVR XII 2 6202, 6228). On kiinnostavaa, että vaikka synnytysloitsujen kohdalla on kyse juuri kivun lievittämisestä, eivät kipujen syntysanat kuitenkaan esiinny aineistossani tämän useammin. Pahantekijöitä ja ongelmia häätäviä taudinkarkotusaihelmia esiintyy säännöllisesti aineistoni loitsuissa, mutta usein kuitenkin lyhyinä pätkinä. Pitkät manausjaksot ovat synnytysloitsuissa harvinaisia.

Synnytysloitsujen osina on käytetty myös voiteen sanoja (SKVR I 941, 945, 976; SKVR VII 4 3032, 3056), löylyn sanoja (SKVR VII 3034), verensulkusanoja (SKVR VI 2 4665; SKVR VII 3026) ja yhden Pohjois-Pohjanmaalta muistiinpannun loitsun osana on katkelma loitsusta vitun vihoja vastaan (SKVR XII 2 6206). Kipujen syntysanojen lailla myös esimerkiksi verensulkusanojen voisi olettaa olleen synnytyksissä tarpeen, mutta hieman yllättäen veren vuotoa on tyrehdytetty vain kahdessa aineistoni loitsussa. Erillisiä verensulkusanoja on kuitenkin voitu hyvin käyttää synnytysloitsujen ohella.

\section{Neitsyt Marian Olemus}

Synnytysloitsut alkavat usein kulloisenkin avustajan nimeämisellä ja kunnioittavalla määrittelyllä. Nimeäminen avaa keskusteluyhteyden avun pyytäjän ja yliluonnollisen avustajan välillä. Kunnioittava puhuttelu ja asenne varmistavat sujuvan yhteistyön tässä tapauksessa synnytyksen edistämiseksi. Määrittelyistä käy ilmi myös se, että loitsun esittäjä tuntee apuun pyytämänsä avustajan luonteen. Pohjois-Karjalasta muistiinpannuissa synnytysloitsuissa Neitsyt Maria kuvaillaan lyhyesti äidiksi: hän 
on "emonen" ja "rakas äiti armollinen" (esim. SKVR VII 3029, 3036, 3037, 3041). Näistä määreistä välittyy voimakas kiintymys ja läheisyys. Yhdessä kiteeläisessä loitsussa Neitsyt Maria on "puhas muori muovollinen" (SKVR VII 4 3033). Kiihtelysvaarasta ja Nurmeksesta tallennetuissa loitsuissa Maria määritellään vanhimmaksi vaimoksi ja ensimmäiseksi äidiksi (SKVR VII 4 3051, 3062). RajaKarjalasta muistiinpannuissa synnytysloitsuissa Maria on yhtä lailla emo ja rakas äiti. Parissa loitsussa Maria määritellään pyhäksi: hän on "pyhä piika pikkarani" (SKVR VII 4 3022, 3023).

Savosta, Vienasta, Pohjois-Pohjanmaalta ja Etelä-Karjalasta muistiinpannuissa synnytysloitsuissa edellä esitellyt määrittelyt toistuvat hyvin samankaltaisina. Muutamissa tapauksissa Maria saa osakseen tavallista pidemmät hyväilyt: Kiimasjärveltä tallennetussa loitsussa Neitsyt Maria on "emoni, / rakas äiti armollinen, / sie olet palveri parahin, / saunavaimoista vakavin" (SKVR I 941) ja Miinoalta peräisin olevassa loitsussa Maria on puolestaan "neitoni emoni, / pyhä piika taivahaini, / kun olet vanhin vaimoloista, / eläjistä ensimäini”" (SKVR I 945). Myös yhdessä Savosta muistiinpannussa loitsussa Maria on poikkeuksellisen pitkästi "emoinen, / rakas äiti armollinen, / siinä paras Sauna Vaimo, / [..], / Helkä vaimo Hembiätar" (SKVR VI 2 4657), mutta niin savolaisissa kuin myös muissa aineistoni loitsuissa Maria on ennen kaikkea emo.

Neitsyt Maria on äiti, mikä yhdistää hänet kipujen keskellä olevaan synnyttäjään. Marian määreet - puhdas, pyhä, armollinen - ovat muutenkin lohduttavia. Maria kuvataan vanhimmaksi vaimoksi ja eläjäksi: hän on ensimmäinen äiti, joka on kokenut ja nähnyt paljon. Maria on yliluonnollinen kätilö, joka tietää ja osaa. Maria on siis ennen kaikkea synnyttänyt nainen, jolla on omakohtaisia kokemuksia. (Ks. Timonen 1990, 138; 1994, 323.) Voiko olla olemassa tämän parempaa avustajaa? Marian voi hyvin sanoa olevan "kaiken hyvän edustaja" (Haavio 1935, 190).

Neitsyt Marian olemuksesta saa tietoa myös aihelmista, joissa kerrotaan tämän ulkomuodosta kuten vaatteista. Etenkin Pohjois-Pohjanmaalta ja Vienasta tallennetuissa loitsuissa Marian ulkoista olemusta kuvaillaan. Nämä aihelmat tuovat esille sen, kuinka vaatteet ja kengät lisäävät Marian elävyyttä ja persoonallisuutta:

[..]

Käys tänne käpein kengin, sukin mustin muibuttele, sukan mustan mustumatta, kastumatta kengän kauon!

[..]

koprin helmas [i] kokooa, käsin keäri voattehesi,

(SKVR I 473 , anonyymi, Uhut. Cajan, 1836.) 


\section{NEITSYT MARIA SYNNYTYSLOITSUISSA}

Sekä Raja- että Pohjois-Karjalasta tallennetut loitsut kertovat harvoin Neitsyt Marian ulkomuodosta. Vain yhdessä suistamolaisessa ja yhdessä liperiläisessä loitsussa mainitaan lyhyesti Marian hameen helmat ja vaatteet (SKVR VII 43018 , 3037). Suojärveltä muistiinpannussa loitsussa "pyhä piigu pikkaraista" pyydetään apuun niin, että "jalka olkaan kengässä / toinen olkaan kengätä" (SKVR VII 3028). Myös maallista kätilöä on Karjalassa kehotettu kiirehtimään apuun samanlaisella fraasilla (Paulaharju 1924, 24; Pentikäinen 1971, 160). Etelä-Karjalan Jaakkimassa Mariaa kehotetaan tulemaan apuun "liinasukkasellaisi" ja "paljailla paiollaisi" (SKVR XIII 9478). Maria on synnytysloitsujen henkilöhahmoisista avustajista ainoa, jonka ulkoista olemusta kuvaillaan jotenkin (7).

Martti Haavion mukaan $(1935,190)$ Neitsyt Maria voi olla pukeutunut loitsuissa myös vahaiseen ja kultaiseen vaippaan, tulipunaiseen pantaan, kultaviilekkeisiin, huntuun ja vaskiseen vyöhön. Synnytysloitsuissa ei kuitenkaan kerrota, että Marian yllä olisi tämänkaltaisia asusteita. Suojeleva vaippa -aihelmaa ei synnytysloitsuissa ole käytetty (ks. Kaukonen 1942, 66-78). Tosin kahdessa Länsi-Inkeristä tallennetussa loitsussa (SKVR III 3 4506, 4511) Mariaa kyllä kuvaillaan määreellä "vahhaine vaimo", mikä voisi viitata Marian vahaiseen vaippaan.

Marian olinpaikasta, josta hänet kutsutaan ihmisten luokse, saa vihiä Mariaa hyväilevistä määreistä. Esimerkiksi Vienan Karjalan Miinoasta tallennetussa loitsussa Neitsyt Maria on "pyhä piika taivahaini” (SKVR I 945), mistä voi nähdä sen, että Marian on käsitetty elävän taivaassa, ylisessä maailmassa. Olinpaikasta saa vihiä myös muutamasta muusta Vienasta kerätystä loitsusta, joissa Marian epäillään olevan joen takana: "jos ollet joven takana, / jouvuos joven takuata" (SKVR I 4 955, 956, 958). Maria on saatava joen takaa liikkeelle ja synnyttäjän avuksi. Kahdessa Etelä-Karjalasta tallennetusta loitsussa puolestaan todetaan, että Neitsyt Maria on nukkumassa (SKVR XIII 3 9466, 9467). Nukkumapaikkaa ei kuitenkaan sen tarkemmin kuvailla, mutta Maria täytyy herättää ennen varsinaista apuun kutsua: "nous ylös makkoaamast, / havaitse nukkumast" (SKVR XIII 3 9466).

\section{"Tules täNne, TARVItAHAN"}

Kuka Mariaa kutsuu apuun synnytysloitsuilla? Harmittavan usein Mariaan vetoavien loitsujen kontekstitiedoista puuttuu loitsun esittäneen ihmisen nimi. Esimerkiksi suurin osa niin Raja-Karjalasta kuin Pohjois-Karjalasta muistiinpannuista synnytysloitsusta on lähtöisin "anonyymin" loitsijan suusta. Jos loitsun esittäjä on nimetty, on se selvästi useammin mies kuin nainen (8). On kiinnostavaa, että joidenkin synnytysloitsujen kontekstitiedoissa mainitaan, että mies on oppinut loitsun isältään tai isoisältään (SKVR VII 4 3019, 3022, 3025, 3069), veljeltään (SKVR VII 3046) tai ylipäätänsä joltakin muulta mieheltä (SKVR VII 3 3039, 3040). On siis selvää, että miehet ovat tunteneet synnytyksiin liittyviä loitsuja. Pohjoiskarjalaisista nimeltä mainituista loitsijoista reilu enemmistö on ollut miehiä ja miehiltä on tallennettu huomattavasti enemmän loitsuja kuin naisilta. Tämä viittaa siihen, että 1800-luvun Pohjois-Karjalassa loitsut ovat olleet enemmän miesten kuin naisten 
perinnettä. Miesten suuren osuuden taustalla on ainakin se tosiasia, että perinteenkerääät haastattelivat naisia useammin miehiä. Kerääjät ohjattiin varsinkin tietäjiksi tunnettujen miesten puheille. (Virtanen 1968, 12; Piela 1989, 100.) Synnytysloitsujen kohdalla on todettava, että Maria-aihelmat kuten esimerkiksi apuun kutsut toistuvat hyvin samankaltaisina riippumatta siitä, onko loitsu tallennettu mieheltä, naiselta tai anonyymiksi jääneeltä taitajalta.

Ilmeistä on kuitenkin se, että aineistoni synnytysloitsuissa Neitsyt Mariaa kutsutaan ennen kaikkea äidin ja lapsen avuksi: piika on päästettävä pinteestä ja matkamies tai pienisormi on vapautettava "pihalle" katsomaan maailmaa. Loitsua käyttänyt tietäjä tai muu loitsimisen taitanut synnytysavustaja pyytää Mariaa muutamassa loitsussa myös omaksi avukseen ja vahvistuksekseen: "avukseni, armokseni, / väjekseni, voimakseni" (SKVR I 950) ja "avuxeni, armoxeni, / levyxeni, lemmexeni, / väexeni, voimaxeni” (SKVR I 960).

Synnytysloitsuissa Marialle annetaan hyvin tarkat ohjeet, joiden mukaan tämän on tultava oikeaan paikkaan oikealla tavalla. Neitsyt Mariaa puhutellaan kuitenkin ensimmäiseksi tämän hyvyyttä korostavilla määreillä, minkä jälkeen hänet pyydetään apuun. Avuun pyynnöissä korostuvat niin avun tarpeellisuus ja kiireellisyys kuin se, että Marian on saavuttava parannuspaikalle saunaan. Mariaa hoputetaan: "tules tänne, tarvitahan, / tule ja tule välehen, / välehenpä siekin jouut, / välehimin tarvitahan" (SKVR VII 3008) ja "käy pian, vällee jouvu, / vällemmin tarvitoa (SKVR $\mathrm{VII}_{4}$ 3053). Vienasta kerättyjen loitsujen avun pyynnöissä toistuvat kliseet "tules tänne tarvitessa, / käyös tänne kutsuossa" (SKVR I 4 945, 953, 954, 956, 959, myös SKVR VI 2 4635). Yhdessä akonlahtelaisessa loitsussa verbi kutsua on korvattu verbillä "käskeä" (SKVR I 950, myös SKVR VI 4641, 4642).

Aineistossani kaikkialla muualla paitsi Etelä-Karjalassa avun pyynnöissä toistuvat Marialle osoitetut ohjeet, kuinka tämän tulee saapua saunaan hiljaa ja kenenkään kuulematta:

\section{Neitsyt Maaria emoinen etc, tule saunaan saloa, alt' uksen, alati seinän; olull' on ukset voija, kasta kaljalla saranat, ettei ukeset ulvojaisi, saranat rääkyjäisi! \\ [..]}

(SKVR VII 43031 , anonyymi, Kitee, Lönnrot 1828.)

Loitsuissa naiset synnyttävät saunassa. Marja-Liisa Keinäsen mukaan naiset suosivat synnytyspaikkoina myös eläinsuojia käytännöllisyyden, yksityisyyden ja niiden tarjoaman lämmön vuoksi. Karjalassa naiset perustelivat eläinsuojan kuten tallin sopivuutta sillä, että myös Neitsyt Maria synnytti Jeesus-lapsen tallissa. Näin Maria osallistui jokaiseen eläinsuojassa tapahtuneeseen synnytykseen. (Keinänen 2003, 120-122.) 
Marialle selitetään usein avun pyynnön yhteydessä tilanteen vakavuus. Synnyttäjän vaikeuksia kuvailemalla loitsija sekä selittää että perustelee sen, miksi avustajaa vaaditaan tulemaan apuun:
Piika piinoa pitävi,
vaimo vaivoa näkevi
hongasessa buonehessa,
pirtissäpetäjäsessä,
miehen mieli juobukia.
Mistä mie anon apua,
kusta etsin huojennusta?
Itse neitsy Marialta.

(SKVR VII 4 3008, anonyymi, Impilahti, Sirelius 1847.)

\section{$[.$.}

Tules tänne tarvitaha,

tänne töibi työlähisi,

asioibi ankaroibi;

Tiäl on piijat pintehissä,

vaimot vatschoin viäntehissä,

honkasessa buonehessa,

pertissä on petäjisessä!

[..]

(SKVR VII 4 3022, Ivan Samsonov, Korpiselkä, Potschtareff, 1897.)

Loitsuissa todistellaan, että kyseessä on oikeasti vakava tilanne, jonka selvittämiseksi avustaja on välttämätön. Hätä ja tuska ovat aineistoni loitsuissa käsin kosketeltavia, mutta itse kuolema mainitaan suhteellisen harvoin. Kuitenkin esimerkiksi Savonrannalta tallennetussa loitsussa kuoleman mahdollisuus sanotaan suoraan: "kohta kuolema tuleepi, / lähestyypi hengen lähtö, / tuohon kohtuun kovaan, / vatsan täyteen vaikeaan" (SKVR VI 2 4641). Myöntäessään ääneen kuoleman läheisyyden loitsijan voi nähdä käyttävän lievää kiristystä ja uhkailua avustajansa suhteen: jos avustaja ei tule auttamaan, korjaa kuolema synnyttäjän ja lapsen. Kuolemasta puhuminen muistuttaa myös ihmisen taitojen rajallisuudesta, mikä edelleen lisää yliluonnollisen avun tarvetta. Erityisen hyvin Neitsyt Marian välttämättömyys ja hädän todellisuus käyvät ilmi, kun loitsija toteaa, että "ei tänne kutšuta syyttä, / ei tahota tarpehetta, / kun asjoi avullisii, / töihe tarpehellisii" (SKVR I 966). Neitsyt Mariaa saapumisen välttämättömyyttä kuvaa myös Kiuruvedeltä muistiinpannun loitsun erikoinen loppu: "ej imento manalle jouda, / tuonen tyttäret toruuvat, / kalman lapset kanteloovat" (SKVR VI 24660 ). 


\section{"OTA KIISKILTÄ KINOO"}

Neitsyt Maria on toiminut loitsuissa yleisauttajana, joskin hänen erikoisalueensa on ollut kipujen lieventäminen lääkkeillä ja voiteilla (Siikala 1992, 170). Myös synnytysloitsuissa Marian oleellisena tehtävänä on parantaminen ja kipujen lievittäminen niin kuin seuraavat esimerkit kertovat:

\section{$[.$.}

Tule tänne! tarvitahan

kivut kijni ottamahan

vajuat vajkuttamahan

päästäpijkaa pintehistä

vaimoo vattan vääntehistä

[..]

(SKVR XII 2 6229, anonyymi, [Pohjanmaa], Reguly, A.Y. Wichmannin

kopio 2. 1840.)

$[.$.

tekemän terfweytä,

raubo rakendaman,

josta saisi Sairas matak,

woisi woibkawa lefwätäk,

[..]

(SKVR VI 2 4656, anonyymi, Savo?, Arvidsson-Bergh, 1700-luv.)

Marian tuo myös synnyttäjän kipuja lieventävää voidetta, "simoa" ja "mettä", josta osa on tarkoitettu juomaksi ja osa ulkoisesti voiteena käytettäväksi (SKVR I 941, 945, 980). Kolmessa Pohjois-Pohjanmaalta tallennetussa toisinnossa on aihelma, jossa Neitsyt Mariaa pyydetään hautomaan kärsivää voiteilla, ”jolla Jesus vojeltihin, / kastettihin kaickivalta" (SKVR XII 6229, 6230, 6231). Ilomantsista kerätyssä loitsussa (SKVR VII 4 3058) Marian tehtävänä on kalan kinalla ja sian lihalla hoitaa voipunutta "jott` ei tuska tunnu päällä, / eikä päällä, eikä alla". Neitsyt Mariaan kipujen lievittäjänä liittyy myös yhdessä loitsussa oleva aihelma, jossa loitsija pyytää Neitsyt Mariaa siirtämään synnyttäjän kivut kiviin: "ei kivi kipuja itke, / paasi vaivoja valita, / vaikka paljo pantanehe, / määrätön mätettänehen" (SKVR VII 4 3057).

Marian voi nähdä voiteita tuovana avustajana myös mehiläisen hahmossa, sillä itäisillä alueilla nämä kaksi on liitetty toisiinsa. Molemmat esiintyvät erityisesti ulkoisia vammoja parantavissa loitsuissa kipujen lieventäjinä. Avuntuojina mehiläiseen ja Neitsyt Mariaan liitetään samoja metaforia ja motiiveja. (Piela 2001, 60; myös Krohn 1915, 222.) Kiteeltä tallennetuissa synnytysloitsuissa mehiläinen tuo voiteeksi hunajaa ja mettä (SKVR VII 4 3032) ja Ilomantsin Mekrijärveltä tallennetussa loitsussa mehiläinen kantaa "Lapin laajalta lahdelta" kalojen kinaa 


\section{NEITSYT MARIA SYNNYTYSLOITSUISSA}

(SKVR VII 3056). Jälkimmäisessä loitsussa loitsija on yhdistänyt mehiläinen tuo voiteita -teeman synnytysloitsuille ominaiseen kalan kinalla voitelemiseen.

Synnytysloitsuissa Marialta pyydetään usein joko kalan kinaa tai jalometallisia työkaluja synnytysteiden avaamista ja lapsen maailmaan vapauttamista varten. Raja- ja Pohjois-Karjalasta tallennetuissa synnytysloitsuissa Neitsyt Mariaa pyydetään lyhyesti ottamaan liukastetta kaloista. Impilahtelaisessa loitsussa Marialle sanotaan, että "ota kiiskiltä kinoa, / matikalta nuljakkoa, / purstosta lohen punasen" (SKVR VII 4 3007) ja pielisjärveläisessä loitsussa Mariaa kehotetaan toimimaan lähes samoilla sanoilla "ota kiiskiltä kinoo, matikalta nuljaskata" (SKVR $\mathrm{VII}_{4}$ 3069). Yhtä lailla molemmissa tapauksissa tarkoituksena on saada äidin synnytystiet liukkaiksi ja lapsi mahdollisimman sujuvasti ulos äitinsä kohdusta. Vaikka sekä raja- että pohjoiskarjalaisissa loitsuissa Marian tehtävänä on ottaa tai tuoda liukastetta, korostuu vienalaisissa ja savolaisissa loitsuissa vielä selkeämmin Marian rooli liukasteen välittäjänä. Neitsyt Mariaa ohjataan kokoamaan hameensa helmat ja menemään veteen hakemaan liukastetta. Seuraavassa esimerkissä tietäjä Poahkomie Omenaini ohjaa avustajaansa Mariaa varsin tarkasti:

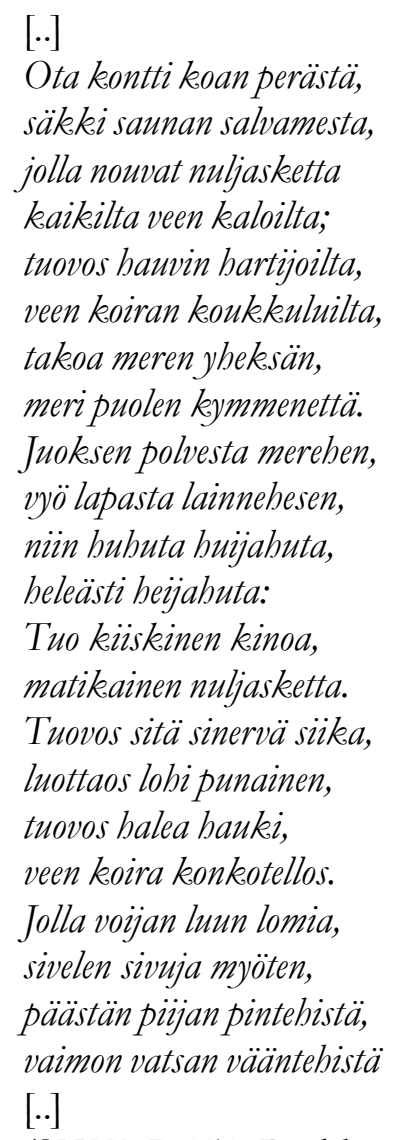




\section{MAarit ViLJAKAinen}

Myös toisessa Vienassa tallennetussa loitsussa Maria ohjataan veteen: "Mäne juossulla jokeh, / viennä virtahan veteh" (SKVR I 949). Savon Haukivuorelta tallennetussa loitsussa Mariaa neuvotaan taas seuraavasti: "Mää rannalle, / siellä huutoo hujauta, / ota kiiskiltä kinaa" (SKVR VI 4 4635). Samuli Paulaharjun mukaan $(1924,28)$ vaikeissa tapauksissa naisen synnytystiet voideltiin hylkeenrasvalla, mer ajulla. Marialta loitsuissa pyydetyn avun voi näin nähdä heijastelevan niitä käytännön toimia, joita synnytyksissä on äidin auttamiseksi kokeiltu.

Toisessa synnytysloitsujen vakioaihelmassa Neitsyt Marialla on käytössään jalometallisia työkaluja tai aseita synnytysteiden aukaisua varten (SKVR I 4 960, 963,

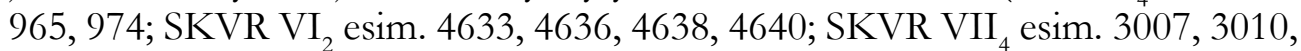
3012, 3014; SKVR XII 2 6224; SKVR XIII 3 esim. 9467, 9478, 9484, 9490). Työkalujen avulla lapsi vapautetaan kohdusta, jota kuvataan lihaiseksi aitaksi tai kellariksi. Lapsen edeltä on avattava luiset portit tai lukot (9). Mariaa kehotetaan tuomaan tai ottamaan tarvittavat apuvälineet:

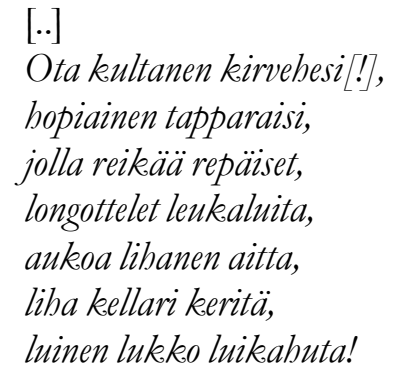

Loitsija pyytää usein samassa loitsussa sekä työkaluja että kinaa: avunpyynnöt ja parantamiseen liittyvät teemat ovat synnytysloitsuissa keskeisiä ja niitä edustaa yhdessä ja samassa loitsussa useampi aihelma (ks. Siikala 1989, 76). Seuraavassa Juvalta poimitussa esimerkissä pyydetään kumpaakin apua. Tarvittava työkalu määritellään poikkeuksellisesti lapsen sukupuolen perusteella:

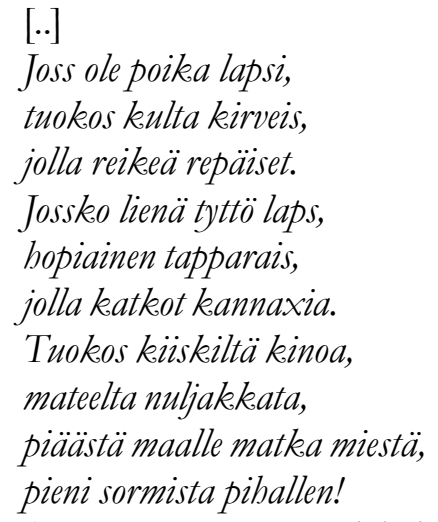


Maria tuo tullessaan nämä apuvälineet ja joko luovuttaa ne loitsijan käyttöön tai käyttää niitä itse synnytyksen nopeuttamiseksi. Muutamassa tapauksessa näyttää siltä, että loitsijalla on työkalut omasta takaa. Impilahtelaisessa loitsussa todetaan Marialle, että "tuos on kultanen kurikka, / hopiainen tapparasi, / jolla luita longottelet" (SKVR VII 4010$)$ ja kiteeläisessä loitsussa todetaan samankaltaisesti, että "tuos on hopiainen kirves, / teräxinen tapparais, / jolla v-a vitaset" (SKVR $\mathrm{VII}_{4}$ 3029). Synnyttäjän maallisen avustajan ja yliluonnollisen avustajan yhteistyö toimii joka tapauksessa saumattomasti. Kumpikin tekee oman osansa yhteisen tavoitteen eteen. Heidi Pankamo on luonnehtinut vienalaisen tietäjän Poahkomie Omenainin suhdetta Neitsyt Mariaan juuri Poahkomielta tallennetun synnytysloitsun perusteella "kahden parantajan tasa-arvoiseksi kumppanuudeksi" $(1995,106)$.

Synnytysloitsuissa korostuu sekä yliluonnollisen avustajan että tämän kanssa yhteistyötä tekevän loitsijan aktiivisuus toimijoina. He avaavat naisen kehon ja vapauttavat lapsen maailmaan. Synnyttäjä on puolestaan passiivinen kärsijä eikä niinkään uuden elämän luoja (10). (Ks. Stark-Arola 1998, 138.) Loitsuissa synnyttävästä naisesta ei juurikaan puhuta. Hän on "piigane pienes kivus, / vaimo vatshan viändehissä" (SKVR VII 4 3019). Synnyttäjä on varsin avuton: "saunassa savun sejassa, / virununna viikon kaiken, / tiijotonna, taijotonna, / tarkasti tajuamatta" (SKVR VII 3034). Marja-Liisa Keinänen esittää $(2003,126)$ kiinnostavan ajatuksen, jonka mukaan loitsu on mahdollistanut kipujen keskellä tyynesti käyttäytyvän ja synnytyksensä salaavan naisen todellisten tunteiden paljastamisen ja ääneen ilmaisemisen. Loitsujen kipeän ja heikon synnyttäjän oli todellisuudessa oltava kivuistaan huolimatta rauhallinen ja normaalisti käyttäytyvä, jotta hän ei olisi paljastunut ulkopuolisille ihmisille.

Neitsyt Marian tehtävissä on havaittavissa joitakin alueellisia painotuksia ja eroavaisuuksia. Vaikka Inkerin alueen synnytysloitsut eivät kuulu artikkelini pääasialliseen aineistoon, on kuitenkin todettava, että Inkerin synnytysloitsuissa kinan haetuttaminen tai sen käyttö ylipäätänsä on täysin vieras aihelma. Samoin Inkerin alueen synnytysloitsuissa avataan harvoin lapsen tie metallisin työkaluin. Avustajilla on työkaluja pääasiassa Itä- ja Pohjois-Inkeristä tallennetuissa toisinnoissa (SKVR $\mathrm{V}_{2}$ 2663, 2665, 2666, 2667, 2668; SKVR IV 4431). Kaiken kaikkiaan inkeriläisissä synnytysloitsuissa avustajia imarrellaan ja kutsutaan paikalle, mutta esimerkiksi Neitsyt Mariaa yksinkertaisesti vain pyydetään päästämään nainen tuskistaan ja avaamaan synnytystiet ilman erikoisia välineitä tai liukasteita. Kahdessa Keski-Inkerin loitsussa (SKVR IV 3 4426, 4427) Marialle annetaan poikkeuksellisesti kaksi vaihtoehtoa:

$[.$.

Jos et tännek itse jovvak,

läbetä sulat sannàs,

heitä helppoist kättès,

böybenist sormueis

$[.$.

(SKVR IV 3 4427, Tarja Radionova, Hevaa, Tynni 1916.) 
Maria voi siis ikään kuin katsoa, näkeekö hän aiheelliseksi saapua apuun vai onko hänellä kenties muita kiireitä, joiden takia hän ei itse fyysisesti ehdi paikalle, mutta hänen sanansa ehtivät ja vaikuttavat loitsijan sanoissa.

Neitsyt Maria toimii myös muutamissa muissa harvemmin esiintyvissä aihelmissa. Häneltä pyydetään kerran rautaisen suoja-aidan rakentamista (SKVR I 973). Ylittämättömän ja alittamattoman aidan on yleensä loitsuissa rakentanut Ukko ylijumala (Siikala 1992, 173-174). Samassa loitsussa Mariaa pyydetään nostamaan maasta vainajia, joita tarvitaan aidan lailla suojaamaan velhoilta ja kateilta. Neitsyt Maria toimii myös parannuspaikan hoitajana eli saunan lämmittäjänä: "lämmitä saloa sauna / pian puilla pikkuisilla, / rikenehen riuahuta" (SKVR XII 2 6211). Mariaa pyydetään tuomaan myös saunaan vasta: "tuoppa vastat tullessasi, / lehet hienot helmoissasi" (SKVR XII 2 6212) tai "tuo vasta varjossasi, / simasulka suojassasi" (SKVR XII 2 6238). Vienalaisissa synnytysloitsuissa esiintyy aihelma, jossa Neitsyt Mariaa pyydetään vapauttamaan lapsi maailmaan saunan kiukaan kiven takaa (SKVR I esim. 949). Lapsen vapauttamisen teema liittyy Lotte Tarkan mukaan useimmiten Luojan virren kohtaukseen, jossa Neitsyt Marian on maaniteltava aurinko sulattamaan hautakallion lukot, joiden takana Jeesus-lapsi on. Tarkka mainitsee myös sammon vapauttamisen kivimäen lukkojen takaa kaloista saatavan nuljaskan eli kinan, voin ja sianlihan avulla. (Tarkka 1990, 250-251).

\section{ESIMERKILLINEN SYNNYTTÄJÄ}

Suistamolta ja Pälkjärveltä on muistiinpantu kaksi synnytysloitsua, jotka poikkeavat suurelta osin kaikista muista SKVR:issa julkaistuista synnytysloitsuista, mutta liittyvät kiinteästi Neitsyt Mariaan. Suistamolaisen loitsun ohessa ei mainita loitsun esittäjää, mutta pälkjärveläinen loitsun on esittänyt 65-vuotias Olli Vasko, joka on kuullut loitsun veljeltään. Näiden loitsujen esittäjät ovat rakentaneet loitsunsa Luojan virren tai Marian virren varaan (SKVR VII 43013,3046$)$. Senni Timonen käsittelee artikkelissaan Karjalan naisten Maria-eepos (1990, myös 1994) tätä laajaa runosikermää, joka on monin paikoin pienoiseepos (11). Timonen keskittyy erityisesti analysoimaan Neitsyt Mariaan liittyviä osarunoja, joista etenkin marjaihme esiintyy synnytysloitsujen osana. Marjaihmeen pituus vaihtelee seitsemästä säkeestä 55 säkeeseen. (Timonen 1990, 117-119.) Synnytysloitsujen osana marjaihme ja osaksi myös koski-ihme on kerrottu suhteellisen pitkästi, koska toinen loitsu sisältää 43 ja toinen 32 säettä.

Marjaihme eli kertomus siitä, miten Maria tulee raskaaksi syötyään marjan tai omenan, on Maria-runoston avainaiheita (Timonen 1990, 119). Suistamolta tallennetun loitsun (SKVR VII 4 3013) alussa Maria siivoaa kotiaan, kunnes hän astuu pirtistään pihalle. Mäeltä hän kuulee marjan houkuttelevan huudon: "tule tyttö, poimimahan, / pää vaski valitsemahan, / tina rinta riipimähän.” Maria menee mäelle, syö marjan ja tulee raskaaksi välittömästi. Maria palaa äitinsä luokse pyytämään, että hän saisi tulla synnyttämään lapsensa kotiin. Äiti ei kuitenkaan suhtaudu tyttäreensä suopeasti vaan kutsuu tätä 'hiien huoraksi”. Maria puolustau- 


\section{NEITSYT MARIA SYNNYTYSLOITSUISSA}

tuu ja selittää tapahtuneen, mutta se, leppyykö äiti, jää epäselväksi. Leppyminen vaikuttaa epätodennäköiseltä. Katkerien sanojen jälkeen loitsussa siirrytään synnytysloitsuille tyypillisempiin Neitsyt Marialle kohdistettuihin avunpyyntöihin.

Pälkjärveltä muistiinpantu loitsu (SKVR VII 4046 ) alkaa mansikan Mariaa houkuttelevalla repliikillä. Maria ei voi taaskaan vastustaa kutsua vaan ottaa marjan ja tulee välittömästi raskaaksi: "tuosta tyyvyin, tuosta täyvyin, / tuosta paksuksi panime, / lihavaksi liittelimme." Tässä loitsussa Maria kuvataan järkyttyneeksi ja itkuiseksi. Isä kysyykin syytä Marian itkulle. Isä toteaa tapahtunutta selvittävälle tyttärelleen, että tämä on raskauteensa syytön. Raskaus ei ole kenenkään tekemä, vaan se on "Luojan suoma". Tämän jälkeen loitsu jatkuu Neitsyt Marialle osoitetuilla avunpyynnöillä.

Marian kotiinpaluun kuvaus kuuluu koski-ihmeeseen, jossa keskeistä on se, että perhe hylkää raskaana olevan tyttären, joka ei toivottomuudessaan näe muuta mahdollisuutta kuin hukuttautua jokeen (Timonen 1990, 122-123). Kahdessa lyhyesti esittelemässäni synnytysloitsussa näyttää käyvän niin, että Suistamon loitsussa Maria jää yksin mutta Pälkjärven tapauksessa häntä ei tuomita. Kuten edellä totesin, kotiinpaluun kuvauksen jälkeen molemmissa loitsuissa siirrytään muihin aihelmiin, eikä Maria ehdi joen äärelle itsemurha-aikeineen. Talli-ihme - kuvaus Marian raskaudesta, ulkopuolisuudesta, lapsen yksinäisestä synnyttämisestä, mutta toisaalta myös syntymän ihmeestä - jää näissä kahdessa loitsussa ehkä hieman yllättäen kertomatta (ks. Timonen 1990, 124-127).

Timosen mukaan $(1990,138)$ Suistamolta ja Pälkjärveltä tallennetut loitsut todistavat Maria-eepoksen toimineen myyttinä riitissä: kun loitsija kertaa ensimmäisen pyhän sikiämisen ja synnyttämisen, tukee hän kulloistakin synnyttäjää, rinnastaa tämän Mariaan ja valmistautuu myös pyytämään Mariaa apuun. Marian synnytys on kaikkien aikojen ensimmäinen synnytys, joka toimii pyhänä mallina kaikille tuleville synnytyksille (Timonen 1990, 126). Maria siis tietää henkilökohtaisesti synnyttäjän kärsimyksen ja yksinäisyyden tuskan hetkellä. Marialla on velvollisuus helpottaa tulevien sukupolvien synnytystuskia, koska hän on ensimmäinen äiti. Paras apu ja tuki tuleekin yleensä semmoiselta, joka on itse kokenut samat koettelemukset. Sekä Suomessa että Karjalassa lapsenpäästäjän tuli olla synnyttänyt nainen, jolla oli omakohtaista kokemusta synnytyksistä (Keinänen 2003, 165, 169). Neitsyt Maria on luotettava avustaja, sillä itsekin yksinäisyyden ja hädän kokeneena hän ei yksinkertaisesti voi hylätä toista samassa tilanteessa olevaa.

\section{LOPUKSI}

Yliluonnolliset avustajahahmot ovat vahvasti läsnä synnytystuskia lievittäneissä ja synnytystä edistäneissä loitsuissa. Synnytysloitsujen keskeiset aihelmat liittyvät yliluonnollisiin avustajiin: loitsija nimeää avustajansa, hyväilee avustajaa tätä kuvaavilla määreillä ja pyytää helpottavaa apua todistellen samalla tilanteen vakavuutta. Loitsuissa maallinen avustaja ja yliluonnollinen avustaja liittoutuvat yhteisen päämäärän eli äidin ja lapsen hyvinvoinnin turvaamiseksi. He tekevät yhteistyötä, sillä 


\section{MaARIT ViLJAKAinen}

kaikki mahdollinen apu ja kaikki käytettävissä olevat tiedot ja taidot ovat olleet tarpeen.

Tässä artikkelissa olen tarkastellut Neitsyt Mariaan liittyviä aihelmia RajaKarjalan, Pohjois-Karjalan, Etelä-Karjalan, Vienan, Savon ja Pohjois-Pohjanmaan synnytysloitsuissa. Maria on vahvasti läsnä ja elävä synnytysloitsuissa niin Vienassa kuin Savossa ja Pohjois-Pohjanmaalla, ja hänen taitoihin turvaudutaan ahkerasti kipuja kärsivän synnyttäjän auttamiseksi. Neitsyt Mariaan otetaan yhteyttä nimeämällä ja määrittelemällä tämä kunnioittavin sanoin. Marian yleisin määre on äiti. Tavallisimmin Maria on lyhyesti "emonen, rakas äiti armollinen". Muutamissa tapauksissa Maria on saanut osakseen tästä jotenkin poikkeavan määritelmän, mutta aineistossani Mariaa kuvaavat määreet ovat hyvin samanlaisia riippumatta siitä, mistä loitsu on tallennettu. Marian kutsuminen äidiksi on tärkeää: Maria on synnyttänyt nainen ja näin ollen hän jakaa jokaisen synnyttäjän kokemukset. Maria on yliluonnollinen kätilö, joka loitsun avulla ohjataan avustamaan äitiä ja lasta. Maria on toisaalta pyhä ja ajaton, mutta toisaalta sekä helposti lähestyttävä että ymmärtävä ja ystävällinen nainen.

Neitsyt Maria näyttäytyy kenkineen ja hameenhelmoineen synnytysloitsujen konkreettisimpana avustajana. Tosin esimerkiksi rajakarjalaisissa, pohjoiskarjalaisissa ja savolaisissa loitsuissa Marian ulkoisen olemuksen kuvaamiseen ei ole juurikaan panostettu, mutta pohjoispohjanmaalaisissa ja vienalaisissa synnytysloitsuissa Marian kengät, sukat ja hameen helmat vilahtelevat toistuvasti. Maria on myös liikkuva avustaja: hänet ohjataan rannalle ja veteen kalojen kinaa hakemaan, minkä jälkeen hänen täytyy vielä toimittaa liukaste parannuspaikalle saunaan. Tämä tulee parhaiten esille vienalaisissa ja savolaisissa synnytysloitsuissa.

Apuun kutsuissa Marialle kerrotaan, että avun tarve on kiireellinen, synnyttäjä on tuskainen ja parannuspaikalle saunaan on saavuttava hiljaa kenenkään kuulematta. Avun pyynnöissä painotetaan Marian tarpeellisuutta ja korostetaan tilanteen vakavuutta: Mariaa ei todellakaan vaivata turhan takia. Loitsuista välittyy kunnioittava asenne, mutta Mariaa kuitenkin ohjataan tarvittavissa toimissa määrätietoisesti. Maria toimii hoitajan, voitelijan, apuvälineiden ja aineiden välittäjän ja synnytysteiden avaajan roolissa. Kaiken taustalla on luonnollisesti tarve vapauttaa sekä synnyttäjä tuskistaan että lapsi pidättävien lukkojen takaa ihmettelemään maailmaa.

\section{VIITTEET}

1) Katolisen kirkon opin mukaan Maria on kaukana tavallisesta ihmisestä: hän on siinnyt synnittömästi ja tullut maailmaan jumalallisena. Ortodoksisessa traditiossa Maria on ihmisen tavoin siinnyt Jumalanäiti, joka sekä Jumalan tahdon että omien valintojensa kautta jumalallistuu. Maria muuttuu armoa saavasta armoa jakavaksi ja näin ollen hän samastuu sekä ihmiseen että Jumalaan. Luterilaisessa traditiossa Mariaa arvostetaan tämän nöyryyden ja hurskauden vuoksi, mutta

liiallinen huomioiminen tulkitaan epäjumalanpalvonnaksi. Erilaiset tulkinnat ovat 
eläneet rinnakkain ja toisiaan muokaten läpäisten tiensä monenlaisina muunnoksina kansanuskoon.

2) Artikkelini aineistossa on niin luterilaisilta kuin ortodoksilta alueilta muistiinpantuja loitsuja. Vaikka en tämän artikkelin puitteissa systemaattisesti vertaile luterilaisilta ja ortodoksilta alueilta kerättyjen synnytysloitsujen Maria-aihelmia, pyrin kuitenkin tuomaan esille samankaltaisuuksia ja eroavaisuuksia eri kulttuurialueiden välillä. Etenkin luterilaisilta ja ortodoksisilta henkilöiltä kerättyjen Maria-loitsujen mahdollisten eroavaisuuksien selvittäminen olisi kiinnostava jatkotutkimuksen aihe.

3) Synnytysloitsut on julkaistu muun muassa "Taudit" ja "Taudit, kivut ja tartunnat" otsikoiden alla. Savon runoissa $\left(\mathrm{SKVR} \mathrm{VI}_{2}\right)$ synnytysloitsut ovat omana lukunaan otsikon "Synnytys, lapsivaimoa ja lasta koskevia varauksia" alla. PohjoisPohjanmaan runoissa (SKVR XII ${ }_{2}$ ) muutama synnytysloitsu on sijoi-tettu otsikon "Lemmennosto, Häät, Perhe-elämä” alle, mutta suurin osa Pohjois-Pohjanmaan synnytysloitsuista löytyy muiden tautiloitsujen joukosta.

4) Yksityiskohtaisemmin suomalaisesta ja karjalaisesta synnytyskulttuurista ja kansanomaisesta synnytysavusta Paulaharju (1924), Pelkonen (1931), Reinilä (1965), Pentikäinen (1971), Helsti (2000) ja Keinänen (2003).

5) Tässä artikkelissa käytän synnytysloitsun esittäjästä käsitettä loitsija. Tällä en kuitenkaan tarkoita pelkästään haltioituvaa tietäjää. Muun muassa Paulaharjun (1924), Pentikäisen (1971), Helstin (2000) ja Keinäsen (2003) tutkimuksista käy ilmi, että synnyttäjää auttoi asiaan perehtynyt naishenkilö tai vaikeissa tapauksissa miestietäjä. Paulaharjun mukaan (1924,20-21) vienankarjalainen synnytysavustaja oli useasti vanhahko nainen ja leskiakka, "joka on niihin toimiin tottunut ja tietää, mitä milloinkin pitää tehdä, osaa kylyssä käytellä, kylvetellä, valella, tehdä tarpeelliset varaustemput ja loitsut lukea". Toisaalta synnyttäjä on voinut myös itse lukea loitsuja, mikäli tämä on niitä taitanut. Yksityiskohtaisemmin karjalaisista synnytysavustajista, ks. Keinänen 2003, 159-180.

6) Huomionarvoinen seikka on se, että yhdessä ja samassa loitsussa voidaan puhutella useampaa avustajaa. Synnytysloitsuja on muistiinpantu ja julkaistu SKVR:issa myös Satakunnasta (SKVR X ${ }_{2}$ ), Uudeltamaalta (SKVR XIV) ja Hämeen alueelta $\left(\right.$ SKVR IX $_{3,4}$ ). Näissä loitsuissa puhutellaan Ukkoa, Jumalaa tai Luojaa. Neitsyt Maria on edellä mainittujen alueiden synnytysloitsuissa mukana vain yhdessä hämäläisessä loitsussa (SKVR IX $\left.{ }_{3,4} 420\right)$. Länsisuomalaisissa synnytysloitsuissa saatetaan puhutella jotakin yliluonnollista avustajaa, mutta avustajaa ei kuitenkaan välttämättä edes nimetä. Näin on laita myös joissakin aineistoni loitsuissa. Ukko ylijumalan kohdalla on kiinnostavaa, että sitä ei tunneta Keski-Inkerin ja Vatjan alueen, eikä myöskään Länsi-Inkerin synnytysloitsuissa. Itä- ja PohjoisInkeristä ja Savosta on molemmilta alueilta tallennettu yhdet loitsut, joissa vedotaan Ukkoon. Etelä-Karjalasta ja Pohjois-Pohjanmaalta on puolestaan tallennettu muutamia Ukon apuun turvautuvia synnytysloitsuja. Esimerkiksi kansanuskon piiriin kuuluvat naispuoliset avustajahahmot Kipu tyttö, Kave eukko ja Synnyttäret esiintyvät muutamassa Raja-Karjalasta, Pohjois-Karjalasta ja Savosta kerätyssä synnytysloitsussa. Vienalaisissa synnytysloitsuissa ei edellä mainitun 
kaltaisia avustajia esiinny lainkaan. Loitsuissa esiintyviä yliluonnollisia avustajia ja tietäjien myyttisiä maailmoja ovat tutkineet Kaarle Krohn (1915), Martti Haavio (1935, 1967), Anna-Leena Siikala (1992), Heidi Pankamo (1995), Ulrika WolfKnuts (1999), Ulla Piela (2001, 2004) ja Maarit Viljakainen (2004). Tarkastelin pro gradu -tutkimuksessani Neitsyt Marian ohella muun muassa Ukko ylijumalan olemusta, apuun kutsua ja Ukolta pyydettyä apua synnytysloitsuissa.

7) Myyttisten apueläinten kuten koiran tai kotkan ulkonäköä voidaan loitsuissa kuvailla varsin tarkasti (Siikala 1992,192,198-205). Kahdessa aineistoni loitsussa apuna on rautakarvainen rakki (SKVR VII 3039; SKVR VI 2 4639) ja yhdessä loitsussa apuun kutsutaan yliluonnollisen suuri ja tulinen kotka (SKVR XII 2 6212).

8) Savosta on tallennettu 18 Mariaan vetoavaa synnytysloitsua, joista 10 on kerätty miehiltä, yksi naiselta, kuusi täysin anonyymiltä ihmiseltä ja kahden loitsun kohdalla esittäjän kohdalla on mainittu vain sukunimi. Vienasta on tallennettu 23 Mariaan vetoavaa loitsua, joista kahdeksan on muistiinpantu miehiltä, seitsemän naisilta, seitsemän täysin anonyymiltä loitsijalta ja yhden loitsun kohdalla esittäjän sukupuoli on muuten epäselvä. Eteläkarjalaisia Mariaan vetoavia loitsuja on yhteensä yhdeksän. Poikkeuksellisesti naisilta on kerätty loitsuja miehiä enemmän: viisi loitsua naisilta, kaksi miehiltä ja anonyymejä on myös kaksi. PohjoisPohjanmaan 12 Maria-loitsusta suurin osa eli 8 loitsua on peräisin anonyymiltä esittäjältä, kun miehiltä on kerätty neljä loitsua. Naista ei ole nimetty yhdenkään loitsun lähteeksi. Anonyymeiksi jääneitä loitsujen osaajia on siis valitettavan paljon. Maria-aihelmat toistuvat kuitenkin aineistossani hyvin samankaltaisina oli loitsu kerätty mieheltä, naiselta tai anonyymiksi jääneeltä ihmiseltä.

9) Pohjoiskarjalainen metsästäjä on pyytänyt loitsuillaan naispuolista metsänhaltijaa avaamaan "luiset lukot" ja "lihaisan aitan", jotta metsästäjä saisi hyvän saaliin (Piela 1989, 94).

10) Kuitenkin Helstin (2000) ja Keinäsen (2003) tutkimuksissa korostuu se, että naiset ovat olleet synnytyksissään varsin aktiivisia toimijoita. Synnytystuskia ei ole kärsitty nöyrästi mukisematta.

11) Myös Kupiainen 2004, 242-245.

\section{TutKimusaineistot}

— SKVR I, Suomen Kansan Vanhat Runot, I:4: Vienan läänin runot. Helsinki: Suomalainen Kirjallisuuden Seura. 1921.

— SKVR VI, Suomen Kansan Vanhat Runot, VI:2: Savon runot. Helsinki: Suomalaisen Kirjallisuuden Seura. 1936.

- SKVR VII 4 , Suomen Kansan Vanhat Runot, VII:4: Raja- ja Pohjois-Karjalan runot. Helsinki: Suomalaisen Kirjallisuuden Seura. 1933.

- SKVR XII 2 , Suomen Kansan Vanhat Runot, XII:2: Pohjois-Pohjanmaan runot. Helsinki: Suomalaisen Kirjallisuuden Seura. 1935.

- SKVR XIII ${ }_{3}$, Suomen Kansan Vanhat Runot, XIII:3: Etelä-Karjalan runot. Helsinki: Suomalaisen Kirjallisuuden Seura. 1939. 


\section{NEITSYT MARIA SYNNYTYSLOITSUISSA}

\section{KiRjallisuUs}

HAAVIO, MARTTI 1935: Suomalaisen muinaisrunouden maailma. Porvoo: WSOY. - 1967: Suomalainen mytologia. Porvoo: WSOY.

HELSTI, HILKKA 2000: Kotisynnytysten aikaan. Etnologinen tutkimus äitiyden ja äitiysvalistuksen konflikteista. Suomalaisen Kirjallisuuden Seuran Toimituksia 785. Helsinki: Suomalaisen Kirjallisuuden Seura.

KAUKONEN, VÄINÖ 1942: "Maarian vakainen vaippa" suomalaisissa loitsurunoissa. Kalevalaseuran vuosikirja 22. Helsinki: Suomalaisen Kirjallisuuden Seura.

KEINÄNEN, MARJA-LIISA 2003: Creating Bodies. Childbirth Practices in Pre-Modern Karelia. Stockholm: Stockholms University.

KROHN, KAARLE 1915: Suomalaisten runojen uskonto. Suomen suvun uskonnot I. Suomalaisen Kirjallisuuden Seuran toimituksia 137. Helsinki: Suomalaisen Kirjallisuuden Seura, WSOY.

KUPIAINEN, TARJA 2004: Kertovan kansanrunouden nuori nainen ja nuori mies. Suomalaisen Kirjallisuuden Seuran Toimituksia 996. Helsinki: Suomalaisen Kirjallisuuden Seura.

PANKAMO, HEIDI 1995: Kabden vienankarjalaisen tietäjän myyttinen maailma. Mïna Huovisen ja Poabkomie Omenainin taika-ja loitsurepertuaarin tarkastelua. Julkaisematon perinteentutkimuksen pro gradu -tutkielma. Joensuu: Joensuun yliopisto. Suomen kielen ja kulttuuritieteiden laitos.

PAULAHARJU, SAMULI 1924: Syntymä, lapsuns ja kuolema. Vienan Karjalan tapoja ja uskomuksia. Porvoo: WSOY.

PELKONEN, ERKKI 1931: Über volkstümliche Geburtshilfe in Finland: Akademische Abhandlung. Acta Societas medicorum Fennicae Duodecim. Helsinki: Societas medicorum Fennica.

PENTIKÄINEN, JUHA 1971: Marina Takalon uskonto. Uskontoantropologinen tutkimus. Suomalaisen Kirjallisuuden Seuran Toimituksia 299. Helsinki: Suomalaisen Kirjallisuuden Seura.

PIELA, ULLA 1989: Loitsut 1800-luvun Pohjois-Karjalassa. - Knuuttila, Seppo \& Laaksonen, Pekka (toim.), Runon ja rajan teillä. Kalevalaseuran vuosikirja 68. Helsinki: Suomalaisen Kirjallisuuden Seura.

— 2001: Aikojen rajat parannusriitissä. - Haanpää, Eeva-Liisa \& Peltonen, UllaMaija \& Saure, Hilpi (toim.), Ajan taju. Kirjoituksia kansanperinteestä ja kirjallisuudesta. Suomalaisen Kirjallisuuden Seuran kirjaston julkaisuja 18. Helsinki: Suomalaisen Kirjallisuuden Seura.

— 2004: Juhana Kainulainen, Elias Lönnrotin ensimmäinen laulaja. - Siikala, AnnaLeena \& Harvilahti, Lauri \& Timonen, Senni (toim.), Kalevala ja laulettu runo. Suomalaisen Kirjallisuuden Seuran Toimituksia 958. Helsinki: Suomalaisen Kirjallisuuden Seura.

PORTHAN, HENRIK GABRIEL 1982: Valitut teokset. Suomalaisen Kirjallisuuden Seuran Toimituksia 373. Helsinki: Suomalaisen Kirjallisuuden Seura.

REINILÄ, ANNA-MARIA 1965: Pirttimuori suomalaisen perinteen valossa. Julkaisematon laudaturtutkielma. Helsinki: Helsingin yliopisto, kansatieteen laitos. 
SIIKALA, ANNA-LEENA 1989: Myyttinen ajattelu ja loitsujen variaatio. - Knuuttila, Seppo \& Laaksonen, Pekka (toim.), Runon ja rajan teillä. Kalevalaseuran vuosikirja 68. Helsinki: Suomalaisen Kirjallisuuden Seura.

- 1992: Suomalainen samanismi. Mielikuvien historiaa. Suomalaisen Kirjallisuuden Seuran Toimituksia 565. Helsinki: Suomalaisen Kirjallisuuden Seura.

— 1996: Kalevalaisen mytologian nainen. - Hakamies, Pekka (toim.), Näkökulmia karjalaiseen perinteeseen. Suomi 182. Helsinki: Suomalaisen Kirjallisuuden Seura.

STARK-AROLA, LAURA 1998: Magic, Body and Social Order. The Construction of Gender Through Women's Private Rituals in Traditional Finland. Studia Fennica Folkloristica 5. Helsinki: Finnish Literature Society.

TARKKA, LOTTE 1990: Tuonpuoleiset, tämänilmanen ja sukupuoli: raja vienankarjalaisessa kansanrunoudessa. - Nenola, Aili \& Timonen, Senni (toim.), Louben sanat. Kirjoituksia kansanperinteen naisista. Suomalaisen Kirjallisuuden Seuran Toimituksia 520. Helsinki: Suomalaisen Kirjallisuuden Seura.

TIMONEN, SENNI 1990: Karjalan naisten Maria-eepos. - Hakamies, Pekka (toim.), Runo, alue ja merkitys. Kirjoituksia vanhan kansanrunon alueellisesta muotoutumisesta. Karjalan tutkimuslaitoksen julkaisuja N:o 92. Joensuu: Joensuun yliopisto.

- 1994: The Mary of Women's Epic. - Siikala, Anna-Leena \& Sinikka Vakimo (eds), Songs beyond the Kalevala: Transformations of Oral Poetry. Studia Fennica Folkloristica 2. Helsinki: Finnish Literature Society.

VILJAKAINEN, MAARIT 2004: Väjekseni, voimakseni, avukseni, armokseni. Tutkimus supranormaaleista avustajista synnytysloitsuissa. Julkaisematon perinteentutkimuksen

pro gradu -tutkielma. Joensuu: Joensuun yliopisto, suomen kielen ja kulttuuritieteiden laitos.

VIRTANEN, LEEA 1968: Kalevalainen laulutapa Karjalassa. Suomi 113:1. Helsinki: Suomalaisen Kirjallisuuden Seura.

WOLF-KNUTS, ULRIKA 1999: The Virgin Mary in Ostrobothnian Magic Spells. - Valk, Ülo (ed.), Studies in Folklore and Popular Religion Vol 2. Papers Delivered at the Symposium Christian Folk Religion. Publications of the Department of Estonian and Comparative Folklore. Tartu: University of Tartu.

\section{FM Maarit Viljakainen on perinteentutkija Joensuun yliopistossa.}

